\title{
PENGARUH PENERAPAN SISTEM MANAJEMEN \\ KESELAMATAN DAN KESEHATAN KERJA (SMK3) TERHADAP PENGAMANAN PROYEK KONSTRUKSI TOWER "X" DI SURABAYA
}

\author{
Mansur $^{1}$ \\ ${ }^{1}$ Program Studi Teknik Sipil, Universitas Narotama \\ Email: mansurifai51@gmail.com
}

\begin{abstract}
ABSTRAK
Penelitian ini bertujuan untuk menganalisis pengaruh penerapan Sistem Manajemen Keselamatan Dan Kesehatan Kerja (SMK3) terhadap produktifitas pekerja proyek konstruksi tower "X" di Surabaya. Populasi yang digunakan adalah karyawan proyek konstruksi tower "X" di Surabaya sebanyak 230 karyawan, sedangkan jumlah sampel diambil 146 karyawan. Data yang digunakan bersumber dari data primer. Pengumpulan data dilakukan dengan menyebarkan kuesioner. Teknik analisis data yang digunakan adalah analisis regresi linier berganda. Hasil dalam penelitian ini menunjukkan bahwa: (1) Faktor Keamanan mempunyai pengaruh signifikan dan positif terhadap Pengamanan Proyek; (2) Faktor Peralatan Dan Pakaian Kerja mempunyai pengaruh signifikan positif terhadap Pengamanan Proyek; (3) Faktor Jalur Kendaraan mempunyai pengaruh signifikan positif terhadap Pengamanan Proyek; (4) Faktor Kebakaran tidak mempunyai pengaruh signifikan terhadap Pengamanan Proyek; (5) Faktor Peralatan dan Mesin mempunyai pengaruh signifikan positif terhadap Pengamanan Proyek; (6) Faktor Listrik dan Suara mempunyai pengaruh signifikan positif terhadap Pengamanan Proyek; (7) Faktor Perlindungan Publik tidak mempunyai pengaruh signifikan terhadap Pengamanan Proyek; (8) Faktor Umum mempunyai pengaruh signifikan positif terhadap Pengamanan Proyek; (9) Faktor Kesehatan Kerja mempunyai pengaruh signifikan positif terhadap Pengamanan Proyek.
\end{abstract}

Kata kunci: Sistem Manajemen Keselamatan Dan Kesehatan Kerja (SMK3), Produktifitas Pekerja

\section{PENDAHULUAN}

Setiap tahun ribuan kecelakaan terjadi ditempat kerja yang menimbulkan korban jiwa, kerusakan materi, dan gangguan produksi. Pada tahun 2018 menurut jamsostek tercatat 173.105 kecelakaan yang mengakibatkan 1.451 orang meninggal, 5.326 orang cacat tetap dan 58.697 orang cedera. Data kecelakaan tersebut mencakup seluruh perusahaan yang menjadi anggota jamsostek dengan jumlah peserta sekitar 7 juta orang atau sekitar $10 \%$ dari seluruh pekerja di Indonesia. Dengan demikian angka kecelakaan mencapai 930 kejadian untuk setiap 100.000 pekerja setiap tahun. Oleh karena itu jumlah kecelakaan keseluruhannya diperkirakan jauh lebih besar. Bahkan menurut penelitian world economic forum pada tahun 2006, angka kematian akibat kecelakaan di Indonesia mencapai 17-18 untuk setiap 100.000 pekerja

Keselamatan dan kesehatan kerja harus dikelola sebagaimana dengan aspek lainnya dalam perusahaan seperti operasi, produksi, logistik, sumber daya manusia, keuangan dan pemasaran. Aspek K3 tidak akan bisa berjalan seperti apa adanya tanpa adanya intervensi dari manajemen berupa upaya terencana untuk mengelolanya. Karena itu ahli K3 sejak awal tahun 1980an berupaya meyakinkan semua pihak khususnya manajemen organisasi untuk menempatkan aspek K3 yang utama setara dengan unsur 
lain dalam organisasi. Hal inilah yang mendorong lahirnya berbagai konsep mengenai manajemen K3. Menurut Kepmenaker 05 tahun 1996, Sistem Manajemen Keselamatan dan Kesehatan Kerja adalah bagian dari sistem secara keseluruhan yang meliputi struktur organisasi, perencanaan/desain, tanggung jawab, pelaksanaan, prosedur, proses, dan sumber daya yang dibutuhkan, bagi pengembangan, penerapan, pencapaian, pengkajian, dan pemeliharaan kebijakan keselamatan dan kesehatan kerja dalam pengendalian resiko yang berkaitan dengan kegiatan kerja diproyek guna terciptanya tempat kerja yang aman, efisien dan produktif.

Salah satu kendala yang mengganjal penerapan Sistem Manajemen Keselamatan dan Kesehatan Kerja (SMK3) pada proyek konstruksi adalah adanya anggapan bahwa penerapan SMK3 disektor konstruksi menggunakan biaya yang tinggi dan apabila pengusaha yang peduli keselamatan kerja para karyawannya apabila memasukkan biaya K3 dalam dokumen penawarannya kemungkinan tidak jadi pemenang tender sebab tawarannya pasti bukanlah tawaran yang terendah. Kecelakaan kerja juga mempengaruhi indeks pembangunan manusia dan daya saing nasional. Oleh karena itu, dalam rangka menekan angka kecelakaan dan penyakit akibat kerja, Kementerian Ketenaga kerjaan berupaya menyempurnakan peraturan perundang-undangan serta standar bidang K3. Oleh sebab itu, pemerintah mengajak seluruh pengusaha, serikat pekerja, pekerja, dan masyarakat untuk terus meningkatkan kesadaran pentingnya K3.

Keselamatan kerja erat bersangkutan dengan peningkatan produksi dan produktivitas. Keselamatan kerja dapat membantu peningkatan produksi dan produktivitas atas dasar : Dengan tingkat keselamatan yang tinggi, kecelakaankecelakaan yang menjadi sebab sakit, cacat dan kematian dapat di tekan sekecilkecilnya. Tingkat keselamatan yang tinggi sejalan dengan pemeliharaan dan penggunaan peralatan kerja dan mesin yang produktif dan efisien dan bertalian dengan tingkat produksi dan produktivitas yang tinggi (Suma'mur, 2009). Dengan demikian, rendahnya keselamatan dan kesehatan kerja tentu akan berdampak pada hasil kerja yang kurang optimal.

Produktivitas pada proyek merupakan besaran volume yang dihasilkan oleh tenaga kerja pada suatu item pekerjaan selama tenggang waktu tertentu. Peningkatan produktivitas akan mengurangi waktu pekerjaan, dan itu berarti akan mereduksi biaya pelaksanaan proyek. Selama ini pelaksana konstruksi menyadari bahwa naik turunnya produktivitas pada pelaksanaan proyek konstruksi dipengaruhi oleh berbagai faktor. Faktor tenaga kerja menjadi prioritas utama yang harus diperhatikan guna menjaga produktivitas tetap baik, karena tenaga kerja berhubungan langsung dengan pelaksanaan proyek. Produktivitas dari tenaga kerja akan berdampak pada kinerja proyek secara keseluruhan. Kinerja proyek merupakan hasil kerja berupa konstruksi bangunan, dari produktivitas seluruh pekerjaan yang dihasilkan oleh tenaga kerja. Oleh karena itu dengan adanya penerapan K3, maka kinerja proyek konstruksi akan semakin baik (Bunial, Muttaqin, \& Rauzana, 2018).

Penerapan K3 pada pelaksanaan proyek konstruksi menurut Bunial, Muttaqin, \& Rauzana (2018) terdiri dari 9 faktor, yaitu faktor keamanan, faktor peralatan dan pakaian kerja, faktor jalur kendaraan, faktor kebakaran, faktor peralatan dan mesin, faktor listrik dan suara, faktor perlindungan publik, faktor umum, dan faktor kesehatan kerja. Hasil penelitian Bunial, Muttaqin, \& Rauzana (2018) membuktikan bahwa pengaruh faktor-faktor penerapan K3 terhadap kinerja proyek konstruksi gedung di Provinsi Aceh, yang berpengaruh signifikan adalah faktor keamanan, peralatan dan pakaian kerja, jalur kendaraan, peralatan dan mesin, perlindungan publik, umum, 
keseriusan perusahaan, dan kompetensi pekerja. Penelitian Desi Supriyan1 dan Ian Rico Andreas Ricardo juga membuktikan bahwa penerapan manajemen K3 memiliki pengaruh positif dan signifikan terhadap kinerja pekerja proyek dalam proyek Cengkareng Business City Lot 5. Christina, Djakfar, \& Thoyib (2012) membuktikan bahwa budaya keselamatan dan kesehatan kerja pada proyek konstruksi perlu dikembangkan karena sangat berpengaruh terhadap kinerja perusahaan. Sehubungan dengan research gap tersebut, maka peneliti berkeinginan untuk menganalisis pengaruh penerapan Sistem Manajemen Keselamatan Dan Kesehatan Kerja (SMK3) terhadap pengamanan proyek konstruksi tower "X" di Surabaya. Semakin baik pelaksanaan K3L di proyek, maka semakin tinggi pengamanan proyek sehingga kinerja proyek akan berjalan lancar. Oleh karena itu, dalam penelitian ini pengamanan proyek diukur dari kinerja proyek itu sendiri.

\section{LANDASAN TEORI}

\section{Keselamatan dan Kesehatan Kerja (K3)}

Pengertian Keselamatan dan Kesehatan Kerja (K3) menurut Kepmenaker R.I. No. Kep. 463/MEN/1993 merupakan upaya perlindungan yang ditujukan agar tenaga kerja dan orang lainnya di tempat kerja/perusahaan selalu dalam keadaan selamat dan sehat, serta agar setiap sumber produksi dapat digunakan secara aman dan efisien. Ervianto (2005) berpendapat bahwa kesehatan dan keselamatan kerja adalah dua hal yang sangat penting. Oleh karenanya, semua perusahaan kontraktor berkewajiban menyediakan semua keperluan peralatan/perlengkapan perlindungan diri.

\section{Pengertian Sistem Manajemen Keselamatan dan Kesehatan Kerja (SMK3)}

Menurut PP No. 50 Tahun 2012, SMK3 adalah bagian dari sistem manajemen perusahaan secara keseluruhan dalam rangka pengendalian resiko yang berkaitan dengan kegiatan kerja guna terciptanya tempat kerja yang aman, efisien dan produktif. Menurut ILO (International Labour Organization), SMK3 adalah ilmu yang bertujuan untuk mengantisipasi, mengevaluasi dan sebagai pengendalian bahaya yang timbul di dalam dan atau dari tempat kerja yang dapat mengganggu kesehatan dan kesejahteraan pekerja, dengan mempertimbangkan kemungkinan dampak pada masyarakat sekitar dan lingkungan umum. Manajemen keselamatan dan kesehatan kerja sendiri adalah proses pengintegrasian atau mengintegrasikan antara prinsip-prinsip keselamatan dan kesehatan kerja ke dalam sistem perusahaan. SMK3 (Sistem Manajemen Keselamatan dan Kesehatan Kerja) tersebut diwajibkan oleh pemerintah Indonesia bagi perusahaan yang memiliki pekerja atau tenaga kerja dengan jumlah melebihi 100 orang dan memiliki tingkat bahaya yang cukup tinggi.

\section{Faktor-faktor yang Berhubungan dengan Penerapan SMK3}

Menurut Bunial, Muttaqin, \& Rauzana (2018), penerapan K3 pada pelaksanaan proyek konstruksi terdiri dari beberapa faktor. Adapun faktor tersebut dapat dilihat pada Tabel 1.

Tabel 1: Faktor-faktor Penerapan K3

\begin{tabular}{|c|l|l|}
\hline No. & \multicolumn{1}{|c|}{ Faktor } & \multicolumn{1}{c|}{ Indikator } \\
\hline 1 & $\begin{array}{l}\text { Faktor } \\
\text { keamanan }\end{array}$ & $\begin{array}{l}\text { Setiap pekerja dalam proyek dapat mencapai tempat kerja dengan } \\
\text { aman }\end{array}$ \\
\cline { 3 - 3 } & Telah terpasang pagar pengaman pada ruang terbuka di dalam proyek \\
\hline
\end{tabular}


VOLUME 4 NOMOR 1 JUNI 2020

\begin{tabular}{|c|c|c|}
\hline No. & Faktor & Indikator \\
\hline & & untuk mencegah terjatuhnya pekerja \\
\hline & & Lokasi proyek memiliki penerangan yang baik \\
\hline & & $\begin{array}{l}\text { Telah terpasang rambu-rambu/tanda-tanda keselamatan kerja pada } \\
\text { area tertentu di proyek }\end{array}$ \\
\hline & & Struktur sementara dalam keadaan stabil dan aman \\
\hline \multirow[t]{4}{*}{2} & \multirow{4}{*}{$\begin{array}{l}\text { Faktor } \\
\text { peralatan dan } \\
\text { pakaian kerja }\end{array}$} & $\begin{array}{l}\text { Perusahaan menyediakan pakaian kerja, helm, sepatu boots, sarung } \\
\text { tangan, masker, sabuk pengaman }\end{array}$ \\
\hline & & $\begin{array}{l}\text { Semua peralatan tersebut dalam kondisi baik dan dapat digunakan } \\
\text { sesuai dengan fungsinya }\end{array}$ \\
\hline & & Para pekerja menggunakan peralatan dan pakaian kerja saat bekerja \\
\hline & & $\begin{array}{l}\text { Perusahaan menyediakan pakaian kerja yang dapat melindungi saat } \\
\text { kondisi hujan }\end{array}$ \\
\hline \multirow[t]{3}{*}{3} & \multirow[t]{3}{*}{$\begin{array}{l}\text { Faktor jalur } \\
\text { kendaraan }\end{array}$} & $\begin{array}{l}\text { Telah tersedia jalur untuk pejalan kaki yang terpisah dari jalur untuk } \\
\text { kendaraan }\end{array}$ \\
\hline & & $\begin{array}{l}\text { Telah tersedia jalur berbalik yang beda untuk menghindari jalur } \\
\text { searah }\end{array}$ \\
\hline & & Semua kendaraan pengangkut dalam kondisi baik atau siap pakai \\
\hline \multirow[t]{5}{*}{4} & \multirow[t]{5}{*}{$\begin{array}{l}\text { Faktor } \\
\text { kebakaran }\end{array}$} & $\begin{array}{l}\text { Telah diberlakukan larangan merokok pada area proyek untuk } \\
\text { menghindari kebakaran }\end{array}$ \\
\hline & & Tersedia alat pemadam kebakaran yang jumlahnya mencukupi \\
\hline & & $\begin{array}{l}\text { Telah diberlakukan pembatasan jumlah material yang mudah } \\
\text { terbakar }\end{array}$ \\
\hline & & $\begin{array}{l}\text { Telah tersedia tempat yang aman untuk area penyimpanan } \\
\text { material/barang yang mudah terbakar }\end{array}$ \\
\hline & & $\begin{array}{l}\text { Telah tersedia tempat pembuangan khusus untuk sisa material/barang } \\
\text { yang mudah terbakar }\end{array}$ \\
\hline \multirow[t]{4}{*}{5} & \multirow{4}{*}{$\begin{array}{l}\text { Faktor } \\
\text { peralatan dan } \\
\text { mesin }\end{array}$} & Pemilihan alat dan mesin sesuai dengan jenis pekerjaan \\
\hline & & an yang berbahaya tel \\
\hline & & Semua mesin dapat dioperasikan dengan baik \\
\hline & & Semua operator cukup berpengalaman dan kompeten \\
\hline \multirow[t]{4}{*}{6} & \multirow{4}{*}{$\begin{array}{l}\text { Faktor listrik } \\
\text { dan suara }\end{array}$} & Semua sambungan kabel telah dipastikan aman \\
\hline & & $\begin{array}{l}\text { Semua kabel baik kabel dalam tanah maupun di permukaan tanah } \\
\text { telah dilindungi dengan baik }\end{array}$ \\
\hline & & Tersedia alat peredam suara pada lokasi proyek \\
\hline & & Tersedia alat pelindung telinga pada lokasi proyek \\
\hline \multirow[t]{3}{*}{7} & \multirow{3}{*}{$\begin{array}{l}\text { Faktor } \\
\text { perlindungan } \\
\text { publik }\end{array}$} & Telah terpasang pagar di sekitar lokasi proyek \\
\hline & & Pintu masuk dan pintu keluar proyek dalam kondisi baik \\
\hline & & $\begin{array}{l}\text { Telah dipasang rambu/informasi mengenai proyek di sekitar lokasi } \\
\text { proyek }\end{array}$ \\
\hline \multirow[t]{5}{*}{8} & \multirow[t]{5}{*}{ Faktor umum } & $\begin{array}{l}\text { Perusahaan mengikutsertakan para pekerja pada pelatihan mengenai } \\
\text { prosedur keselamatan kerja }\end{array}$ \\
\hline & & $\begin{array}{l}\text { Perusahaan memiliki peraturan yang jelas mengenai prosedur } \\
\text { keselamatan kerja }\end{array}$ \\
\hline & & $\begin{array}{l}\text { Perusahaan memberlakukan pemberian } \\
\text { peraturan tersebut }\end{array}$ \\
\hline & & $\begin{array}{l}\text { Perusahaan melakukan identifikasi secara menyeluruh terhadap } \\
\text { kecelakaan kerja yang pernah terjadi sebelumnya }\end{array}$ \\
\hline & & $\begin{array}{l}\text { Terdapat jalur-jalur penyelamatan yang cukup sebagai jalur alternatif } \\
\text { dalam keadaan darurat }\end{array}$ \\
\hline 9 & Faktor & Tersedia kamar mandi dalam jumlah yang cukup \\
\hline
\end{tabular}




\begin{tabular}{|c|c|c|}
\hline No. & Faktor & Indikator \\
\hline & \multirow{5}{*}{$\begin{array}{l}\text { kesehatan } \\
\text { kerja }\end{array}$} & Telah diberlakukan tugas piket untuk kebersihan sarana MCK \\
\hline & & Tersedia ruang untuk beristirahat bagi para pekerja \\
\hline & & $\begin{array}{l}\text { Tersedia dapur bagi pekerja untuk menyiapkan makanan dan } \\
\text { minuman }\end{array}$ \\
\hline & & Tersedia air minum dengan jumlah yang memadai \\
\hline & & $\begin{array}{l}\text { Tersedia obat-obatan untuk pertolongan pertama apabila terjadi } \\
\text { kecelakaan }\end{array}$ \\
\hline
\end{tabular}

Sumber: Wisandjojo (2013) dalam Bunial, Muttaqin, \& Rauzana (2018)

\section{METODE PENELITIAN}

Penelitian ini menggunakan jenis penelitian kausalitas dengan pendekatan kuantitatif. Penelitian yang gunakan oleh peneliti juga lebih kepada penelitian yang bersifat diskriptif (descriptive research). Dalam penelitian ini populasinya adalah karyawan proyek konstruksi tower "X" di Surabaya sebanyak 230 karyawan. Teknik penarikan sampel dalam penelitian ini menggunakan proporsional sampling. Jadi sampel yang digunakan dalam penelitian ini sebanyak 146 karyawan proyek konstruksi tower " $X$ " di Surabaya yang telah bekerja minimal selama 1 tahun dan dengan pertimbangan karyawan yang mengisi kuisioner merupakan karyawan yang benar-benar mengerti tentang proyek konstruksi. Dalam penelitian ini, guna mendapatkan data yang dibutuhkan, maka penulis menggunakan pengumpulan data melalui sumber data primer. Sumber data primer yang digunakan dalam penelitian ini adalah dengan metode penyebaran kuesioner. Analisis data yang digunakan dalam penelitian ini adalah analisis regresi linier berganda.

\section{HASIL DAN PEMBAHASAN}

\section{Analisis Regresi Linier Berganda}

Analisis data yang digunakan dalam penelitian ini adalah regresi linear berganda yang digunakan untuk mengetahui faktor-faktor yang mempengaruhi penerapan Sistem Manajemen Keselamatan Dan Kesehatan Kerja (SMK3) pada proyek konstruksi tower "X" di Surabaya. Berdasarkan dari hasil perhitungan pengolahan data dengan bantuan komputer program SPSS for windows maka diperoleh persamaan regresi linier berganda pada Tabel 2.

Tabel 2: Hasil Analisis Regresi Linier Berganda

\begin{tabular}{|l|c|c|}
\hline \multirow{2}{*}{\multicolumn{1}{|c|}{ Model }} & \multicolumn{2}{c|}{ Unstandardized Coefficients } \\
\cline { 2 - 3 } & $\boldsymbol{B}$ & Std. Error \\
\hline Constant & 0.024 & 0.083 \\
\hline Faktor Keamanan $\left(\mathrm{X}_{1}\right)$ & 0.121 & 0.056 \\
\hline Faktor Peralatan Dan Pakaian Kerja $\left(\mathrm{X}_{2}\right)$ & 0.224 & 0.051 \\
\hline Faktor Jalur Kendaraan $\left(\mathrm{X}_{3}\right)$ & 0.104 & 0.046 \\
\hline Faktor Kebakaran $\left(\mathrm{X}_{4}\right)$ & 0.072 & 0.049 \\
\hline Faktor Peralatan dan Mesin $\left(\mathrm{X}_{5}\right)$ & 0.172 & 0.042 \\
\hline Faktor Listrik dan Suara $\left(\mathrm{X}_{6}\right)$ & 0.082 & 0.041 \\
\hline Faktor Perlindungan Publik $\left(\mathrm{X}_{7}\right)$ & 0.058 & 0.039 \\
\hline Faktor Umum $\left(\mathrm{X}_{8}\right)$ & 0.128 & 0.061 \\
\hline Faktor Kesehatan Kerja $\left(\mathrm{X}_{9}\right)$ & 0.156 & 0.061 \\
\hline
\end{tabular}


Berdasarkan hasil perhitungan tersebut diatas, diperoleh persamaan regresi linier berganda yang signifikan sebagai berikut:

$$
\begin{gathered}
Y=0.024+0.121 X_{1}+0.224 X_{2}+0.104 X_{3}+0.072 X_{4}+0.172 X_{5}+0.082 X_{6}+ \\
0.058 X_{7}+0.128 X_{8}+0.156 X_{9}
\end{gathered}
$$

\section{Koefisien Korelasi Berganda $(\mathbf{R})$ dan Determinasi Berganda $\left(\mathbf{R}^{2}\right)$}

Tabel 3: Koefisien Korelasi Dan Koefisien Determinasi

\begin{tabular}{|r|r|r|r|r|}
\hline Model & $\mathbf{R}$ & $\mathbf{R}_{\text {Square }}$ & Adjusted $\boldsymbol{R}_{\text {Square }}$ & Std. Error of Estimate \\
\hline 1 & $0.974^{\mathrm{a}}$ & 0.948 & 0.945 & 0.15782 \\
\hline
\end{tabular}

Nilai koefisien korelasi (R) menunjukkan seberapa erat hubungan antara faktorfaktor yang mempengaruhi penerapan Sistem Manajemen Keselamatan Dan Kesehatan Kerja (SMK3) pada proyek konstruksi tower "X" di Surabaya, besarnya nilai koefisien korelasi adalah 0.974. Nilai tersebut menunjukkan bahwa hubungan seluruh faktor dalam penelitian ini dengan variabel Pengamanan Proyek (Y) adalah sangat kuat karena nilai korelasi 0.974 mendekati angka satu.

Nilai koefisien determinasi atau $\mathrm{R}^{2}$ digunakan untuk mengukur seberapa jauh kemampuan model dalam menerangkan variasi variabel tak bebas atau variabel terikat yaitu variabel Pengamanan Proyek. Hasil dari perhitungan SPSS diperoleh nilai $\mathrm{R}^{2}=$ 0.948 yang berarti bahwa sebesar 94.8\% Pengamanan Proyek dapat dijelaskan oleh Faktor Keamanan $\left(\mathrm{X}_{1}\right)$, Faktor Peralatan Dan Pakaian Kerja $\left(\mathrm{X}_{2}\right)$, Faktor Jalur Kendaraan $\left(\mathrm{X}_{3}\right)$, Faktor Kebakaran $\left(\mathrm{X}_{4}\right)$, Faktor Peralatan dan Mesin $\left(\mathrm{X}_{5}\right)$, Faktor Listrik dan Suara $\left(\mathrm{X}_{6}\right)$, Faktor Perlindungan Publik $\left(\mathrm{X}_{7}\right)$, Faktor Umum $\left(\mathrm{X}_{8}\right)$, dan Faktor Kesehatan Kerja $\left(\mathrm{X}_{9}\right)$. Sedangkan sisanya $5.2 \%$ dipengaruhi oleh variabel lain diluar model yang diteliti.

\section{Uji F (Uji Kelayakan Model)}

Uji $\mathrm{F}$ bertujuan untuk menguji mengetahui apakah variabel independen layak dalam membentuk variabel dependen. Apakah variabel yang digunakan tersebut layak saat terdapat pengaruh signifikan atau tidak ketika diuji.

Tabel 4: Hasil Perhitungan Uji F

\begin{tabular}{|cl|r|r|r|r|c|}
\hline Model & & Sum of Square & df & Mean Square & F & Sig \\
\hline \multirow{2}{*}{1} & Regresion & 62.078 & 9 & 6.898 & 276.935 & 0.000 \\
\cline { 3 - 7 } & $\begin{array}{l}\text { Residual } \\
\text { Total }\end{array}$ & 3.387 & 136 & 0.025 & & \\
\cline { 3 - 7 } & & 65.465 & 145 & & & \\
\hline
\end{tabular}

Berdasarkan Tabel 4 besarnya nilai signifikansi adalah 0.000 berarti $<0,05$. Hal ini menunjukan bahwa $\mathrm{H}_{0}$ ditolak dan $\mathrm{H}_{1}$ diterima. Sehingga variabel bebas yang terdiri dari Faktor Keamanan $\left(\mathrm{X}_{1}\right)$, Faktor Peralatan Dan Pakaian Kerja $\left(\mathrm{X}_{2}\right)$, Faktor Jalur Kendaraan $\left(\mathrm{X}_{3}\right)$, Faktor Kebakaran $\left(\mathrm{X}_{4}\right)$, Faktor Peralatan dan Mesin $\left(\mathrm{X}_{5}\right)$, Faktor Listrik dan Suara $\left(\mathrm{X}_{6}\right)$, Faktor Perlindungan Publik $\left(\mathrm{X}_{7}\right)$, Faktor Umum $\left(\mathrm{X}_{8}\right)$, dan Faktor Kesehatan Kerja $\left(\mathrm{X}_{9}\right)$ berpengaruh secara simultan terhadap variabel Pengamanan Proyek (Y).

Uji t (Uji Parsial) 
Untuk menguji hipotesis digunakan uji t yang menunjukkan pengaruh secara parsial dari masing-masing variabel bebas terhadap variabel tak bebas. Pada tahapan ini dilakukan pengujian terhadap pengaruh variabel bebas yang terdapat pada model yang terbentuk untuk mengetahui apakah variabel bebas (X) yang ada dalam model secara parsial mempunyai pengaruh yang signifikan terhadap variabel tak bebas (Y)

Tabel 5: Hasil Uji t

\begin{tabular}{|l|c|c|}
\hline \multirow{2}{*}{ Variabel } & \multicolumn{2}{c|}{ Uji t } \\
\cline { 2 - 3 } & thitung & Sig \\
\hline Faktor Keamanan $\left(\mathrm{X}_{1}\right)$ & 2.169 & 0.032 \\
\hline Faktor Peralatan Dan Pakaian Kerja $\left(\mathrm{X}_{2}\right)$ & 4.389 & 0.000 \\
\hline Faktor Jalur Kendaraan $\left(\mathrm{X}_{3}\right)$ & 2.245 & 0.026 \\
\hline Faktor Kebakaran $\left(\mathrm{X}_{4}\right)$ & 1.469 & 0.144 \\
\hline Faktor Peralatan dan Mesin $\left(\mathrm{X}_{5}\right)$ & 4.055 & 0.000 \\
\hline Faktor Listrik dan Suara $\left(\mathrm{X}_{6}\right)$ & 2.013 & 0.046 \\
\hline Faktor Perlindungan Publik $\left(\mathrm{X}_{7}\right)$ & 1.502 & 0.135 \\
\hline Faktor Umum $\left(\mathrm{X}_{8}\right)$ & 2.091 & 0.038 \\
\hline Faktor Kesehatan Kerja $\left(\mathrm{X}_{9}\right)$ & 2.566 & 0.011 \\
\hline
\end{tabular}

1) Uji t (parsial) pada variabel Faktor Keamanan $\left(X_{1}\right)$

Berdasarkan hasil pengolahan data penelitian, diperoleh nilai sig sebesar $0.032<0,05$, maka $\mathrm{H}_{0}$ ditolak pada tingkat signifikansi $5 \%$ sehingga kesimpulannya adalah variabel Faktor Keamanan $\left(\mathrm{X}_{1}\right)$ mempunyai pengaruh signifikan dan positif terhadap Pengamanan Proyek.

2) Uji t (parsial) pada variabel Faktor Peralatan Dan Pakaian Kerja (X2):

Berdasarkan hasil pengolahan data penelitian, diperoleh nilai sig sebesar $0.000<0,05$, maka $\mathrm{H} 0$ ditolak pada tingkat signifikansi 5\% sehingga kesimpulannya adalah variabel Faktor Peralatan Dan Pakaian Kerja (X2) mempunyai pengaruh signifikan positif terhadap Pengamanan Proyek.

3) Uji t (parsial) pada variabel Faktor Jalur Kendaraan (X3):

Berdasarkan hasil pengolahan data penelitian, diperoleh nilai sig sebesar $0.026<0,05$, maka H0 ditolak pada tingkat signifikansi 5\% sehingga kesimpulannya adalah variabel Faktor Jalur Kendaraan (X3) mempunyai pengaruh signifikan positif terhadap Pengamanan Proyek.

4) Uji t (parsial) pada variabel Faktor Kebakaran (X4)

Berdasarkan hasil pengolahan data penelitian, diperoleh nilai sig sebesar $0.144<0,05$, maka H0 ditolak pada tingkat signifikansi 5\% sehingga kesimpulannya adalah variabel Faktor Kebakaran (X4) tidak mempunyai pengaruh signifikan terhadap Pengamanan Proyek.

5) Uji t (parsial) pada variabel Faktor Peralatan dan Mesin (X5):

Berdasarkan hasil pengolahan data penelitian, diperoleh nilai sig sebesar $0.000<0,05$, maka H0 ditolak pada tingkat signifikansi 5\% sehingga kesimpulannya adalah variabel Faktor Peralatan dan Mesin (X5) mempunyai pengaruh signifikan positif terhadap Pengamanan Proyek.

6) Uji t (parsial) pada variabel Faktor Listrik dan Suara (X6):

Berdasarkan hasil pengolahan data penelitian, diperoleh nilai sig sebesar $0.046<0,05$, maka H0 ditolak pada tingkat signifikansi 5\% sehingga 
kesimpulannya adalah variabel Faktor Listrik dan Suara (X6) mempunyai pengaruh signifikan positif terhadap Pengamanan Proyek.

7) Uji t (parsial) pada variabel Faktor Perlindungan Publik (X7)

Berdasarkan hasil pengolahan data penelitian, diperoleh nilai sig sebesar $0.135<0,05$, maka $\mathrm{H} 0$ ditolak pada tingkat signifikansi 5\% sehingga kesimpulannya adalah variabel Faktor Perlindungan Publik (X7) tidak mempunyai pengaruh signifikan terhadap Pengamanan Proyek.

8) Uji t (parsial) pada variabel Faktor Umum (X8):

Berdasarkan hasil pengolahan data penelitian, diperoleh nilai sig sebesar $0.038<0,05$, maka H0 ditolak pada tingkat signifikansi 5\% sehingga kesimpulannya adalah variabel Faktor Umum (X8) mempunyai pengaruh signifikan positif terhadap Pengamanan Proyek.

9) Uji t (parsial) pada variabel Faktor Kesehatan Kerja (X9):

Berdasarkan hasil pengolahan data penelitian, diperoleh nilai sig sebesar $0.011<0,05$, maka $\mathrm{H} 0$ ditolak pada tingkat signifikansi 5\% sehingga kesimpulannya adalah variabel Faktor Kesehatan Kerja (X9) mempunyai pengaruh signifikan positif terhadap Pengamanan Proyek.

\section{PEMBAHASAN}

\section{Pengaruh Faktor Keamanan Terhadap Pengamanan Proyek Konstruksi}

Berdasarkan hasil pengujian hipotesis melalui uji t, diperoleh hasil bahwa Faktor Keamanan berpengaruh signifikan terhadap Pengamanan Proyek Konstruksi, yang dibuktikan dari nilai Sig sebesar 0.032, dengan melihat hasil ini maka dapat diartikan bahwa pengamanan proyek konstruksi yang baik dapat ditingkatkan melalui adanya faktor keamanan yang baik.

Keamanan kerja adalah suatu usaha untuk menjaga dan melindungi pekerja dan fasilitas/aset yang dimiliki, baik yang berada di dalam Kantor maupun yang berada di luar lingkungan Kantor. Upaya memberikan jaminan keamanan kerja tidak hanya diperuntukkan bagi tenaga kerja yang bekerja di dalam lingkungan Kantor, tetapi juga bagi tenaga kerja yang bekerja di lapangan, misalnya: Pegawai bank yang bertugas mengambil atau mengantarkan uang ke suatu tempat perlu mendapat pengawalan yang ketat untuk mengantisipasi tindak kejahatan (Safriansyah \& Naim, 2019).

Hasil temuan ini mendukung temuan Bunial, Muttaqin, \& Rauzana (2018) yang membuktikan bahwa faktor keamanan berpengaruh signifikan terhadap kinerja proyek konstruksi gedung di Provinsi Aceh. Hasil yang sama juga dibuktikan oleh Safriansyah dan Naim (2019) yang menemukan dalam penelitiannya bahwa Keamanan Kerja berpengaruh terhadap Kinerja.

\section{Pengaruh Faktor Peralatan Dan Pakaian Kerja Terhadap Pengamanan Proyek Konstruksi}

Berdasarkan hasil pengujian hipotesis melalui uji t, diperoleh hasil bahwa Faktor Peralatan Dan Pakaian Kerja berpengaruh signifikan terhadap Pengamanan Proyek Konstruksi, yang dibuktikan dari nilai Sig sebesar 0.000, dengan melihat hasil ini maka dapat diartikan bahwa Pengamanan Proyek Konstruksi yang baik dipengaruhi dengan adanya faktor peralatan dan pakaian kerja yang menunjang.

Hasil pada pengujian hipotesis diketahui bahwa faktor peralayan dan pakaian mampu mempengaruhi pengamanan proyek konstruksi secara signifikan dengan pengaruh yang positif atau searah. Hal ini dapat diartikann bahwa peralatan dan pakaian 
kerja yang menunjang pekerjaan akan meningkatkan pengamanan proyek konstruksi. Namun hal ini tidak sama dengan temuan penelitian yang dilakukan oleh Bunial, Muttaqin, \& Rauzana (2018) dimana dalam penelitiannya dibuktikan bahwa faktor peralatan dan pakaian kerja mempunyai hubungan yang rendah terhadap kinerja proyek konstruksi.

\section{Pengaruh Faktor Jalur Kendaraan Terhadap Pengamanan Proyek Konstruksi}

Berdasarkan hasil pengujian hipotesis melalui uji t, diperoleh hasil bahwa Faktor Jalur Kendaraan berpengaruh signifikan terhadap Pengamanan Proyek Konstruksi, yang dibuktikan dari nilai Sig sebesar 0.026, dengan melihat hasil ini maka dapat diartikan bahwa Pengamanan Proyek Konstruksi yang baik dapat dipengaruhi oleh jalur kendaraan yang memadai dan baik.

Hasil pengujian hipotesis dibuktikan bahwa faktor jalur kendaraan mampu mempengaruhi pengamanan proyek konstruksi secara signifikan. Dalam hasil pengujian hipotesis juga diketahui adanya pengaruh secara positif antara kedua variabel tersebut, yang mengindikasikan bahwa semakin baik jalur kendaraan yang ada, maka akan semakin mempengaruhi tingkat pengamanan proyek konstruksi. Namun, temuan ini tidak sama dengan temuan penelitian yang dilakukan oleh Bunial, Muttaqin, \& Rauzana (2018) dimana dalam temuannya ditemukan bahwa jalur kendaraan mempunyai hubungan yang rendah terhadap kinerja proyek konstruksi.

\section{Pengaruh Faktor Kebakaran Terhadap Pengamanan Proyek Konstruksi}

Berdasarkan hasil pengujian hipotesis melalui uji t, diperoleh hasil bahwa Faktor Kebakaran tidak berpengaruh signifikan terhadap Pengamanan Proyek Konstruksi, yang dibuktikan dari nilai Sig sebesar 0.144, dengan melihat hasil ini maka dapat diartikan bahwa Pengamanan Proyek Konstruksi yang baik belum tentu dapat dipengaruhi oleh faktor kebakaran yang terjadi.

Hasil temuan dibuktikan bahwa faktor kebakaran tidak berpengaruh signifikan terhadap pengamanan proyek konstruksi namun memiliki pengaruh positif. Hal ini menunjukkan bahwa faktor kebakaran yang diperhatikan secara baik akan mampu meningkatkan pengamanan proyek konstruksi namun kecil pengaruhnya karena memiliki pengaruh yang tidak signifikan. Hal ini sejalan dengan temuan penelitian Bunial, Muttaqin, \& Rauzana (2018) karena didalam penelitinnya ditemukan bahwa faktor kebakaran mempunyai hubungan yang sangat rendah terhadap kinerja proyek konstruksi.

\section{Pengaruh Faktor Peralatan Dan Mesin Terhadap Pengamanan Proyek Konstruksi}

Berdasarkan hasil pengujian hipotesis melalui uji t, diperoleh hasil bahwa Faktor Peralatan Dan Mesin berpengaruh signifikan terhadap Pengamanan Proyek Konstruksi, yang dibuktikan dari nilai Sig sebesar 0.000, dengan melihat hasil ini maka dapat diartikan bahwa Pengamanan Proyek Konstruksi yang baik dapat ditingkatkan dipengaruhi oleh adanya faktor peralatan dan mesin yang menunjang.

Tingkat keselamatan yang tinggi sejalan dengan pemeliharaan dan penggunaan peralatan kerja dan mesin yang produktif dan efisien dan bertalian dengan tingkat produksi dan produktivitas yang tinggi (Suma'mur, 2009). Dengan demikian, rendahnya keselamatan dan kesehatan kerja tentu akan berdampak pada hasil kerja yang kurang optimal. Namun, hasil ini menolak temuan penelitian Bunial, Muttaqin, \& Rauzana 
(2018) yang membuktikan dalam penelitiannya bahwa peralatan dan mesin mempunyai hubungan yang rendah terhadap kinerja proyek konstruksi gedung di Provinsi Aceh.

\section{Pengaruh Faktor Listrik Dan Suara Terhadap Pengamanan Proyek Konstruksi}

Berdasarkan hasil pengujian hipotesis melalui uji t, diperoleh hasil bahwa Faktor

Listrik Dan Suara berpengaruh signifikan terhadap Pengamanan Proyek Konstruksi, yang dibuktikan dari nilai Sig sebesar 0.046, dengan melihat hasil ini maka dapat diartikan bahwa Pengamanan Proyek Konstruksi yang baik dapat dipengaruhi dengan faktor listrik dan suara yang ada.

Berdasarkan hasil analisis dibuktikan bahwa faktor listrik dan suara memiliki pengaruh yang signifikan terhadap pengamanan proyek konstruksi. Dengan melihat hasil ini maka dapat diartikan bahwa semakin diperhatikannya faktor listrik dan suara dalam proyek konstruksi maka akan semakin dapat meningkatkan tingkat pengamanan proyek konstruksi. Temuan dalam penelitian ini tidak mendukung temuan penelitian Bunial, Muttaqin, \& Rauzana (2018) dimana dalam penelitiannya ditemukan hasil yang berbeda yaitu listrik dan suara mempunyai hubungan yang sangat rendah terhadap kinerja proyek konstruksi gedung.

\section{Pengaruh Faktor Perlindungan Publik Terhadap Pengamanan Proyek Konstruksi}

Berdasarkan hasil pengujian hipotesis melalui uji t, diperoleh hasil bahwa Faktor Perlindungan Publik tidak berpengaruh signifikan terhadap Pengamanan Proyek Konstruksi, yang dibuktikan dari nilai Sig sebesar 0.135, dengan melihat hasil ini maka dapat diartikan bahwa Pengamanan Proyek Konstruksi yang baik tidak dipengaruhi oleh adanya faktor perlindungan publik.

Hasil temuan dibuktikan bahwa faktor perlindungan publik memiliki pengaruh terhadap pengamanan proyek konstruksi secara positif namun tidak signifikan. Hal ini mengindikasikan bahwa faktor perlindungan publik dapat mempengaruhi tingkat pengamanan proyek konstruksi namun sangat rendah pengaruhnya karena hasil yang diperoleh adalah tidak signifikan. Hal ini juga didukung oleh temuan penelitian Bunial, Muttaqin, \& Rauzana (2018) dimana dalam temuannya dibuktikan bahwa perlindungan publik mempunyai hubungan yang sangat rendah terhadap kinerja proyek konstruksi gedung.

\section{Pengaruh Faktor Umum Terhadap Pengamanan Proyek Konstruksi}

Berdasarkan hasil pengujian hipotesis melalui uji t, diperoleh hasil bahwa Faktor Umum berpengaruh signifikan terhadap Pengamanan Proyek Konstruksi, yang dibuktikan dari nilai Sig sebesar 0.038, dengan melihat hasil ini maka dapat diartikan bahwa Pengamanan Proyek Konstruksi yang baik dapat ditingkatkan dengan adanya faktor umum yang menunjang.

Hasil analisis diketahui bahwa factor umum mampu mempengaruhi pengamanan proyek secara signifikan secara positif. Hal ini dapat diartikan bahwa factor umum yang semakin baik dalam sebuah proyek konstruksi akan mampu memberikan kontribusi yang besar dalam mempengaruhi tingkat pengamanan proyek konstruksi. Namun hal ini bertolak belakang dengan temuan penelitian yang dilakukan oleh Bunial, Muttaqin, \& Rauzana (2018) yang membuktikan bahwa factor umum mempunyai hubungan yang sangat rendah terhadap kinerja proyek konstruksi. 


\section{Pengaruh Faktor Kesehatan Kerja Terhadap Pengamanan Proyek Konstruksi}

Berdasarkan hasil pengujian hipotesis melalui uji t, diperoleh hasil bahwa Faktor Kesehatan Kerja berpengaruh signifikan terhadap Pengamanan Proyek Konstruksi, yang dibuktikan dari nilai Sig sebesar 0.011, dengan melihat hasil ini maka dapat diartikan bahwa Pengamanan Proyek Konstruksi yang baik dapat dipengaruhi oleh tingkat faktor kesehatan kerja yang menunjang.

Hasil analisis dibuktikan adanya pengaruh yang signifikan secara positif antara factor kesehatan kerja dengan pengamanan proyek konstruksi. Hal ini dapat diartikan bahwa tingkat faktor kesehatan kerja yang semakin diperhatikan maka akan meningkatkan pengamanan proyek konstruksi saat berlangsung. Menurut Mangkunegara (2013) program kesehatan kerja menunjukkan pada kondisi yang bebas dari gangguan fisik, mental, emosi atau rasa sakit yang disebabkan oleh lingkungan. Resiko kesehatan merupakan faktor-faktor dalam lingkungan kerja yang bekerja melebihi periode waktu yang ditentukan. Lingkungan dapat membuat tekanan emosi atau gangguan fisik.

\section{PENUTUP}

\section{Kesimpulan}

Berdasarkan analisis dan hasil penelitian yang diperoleh, maka kesimpulan dalam penelitian ini adalah sebagai berikut:

1. Faktor Keamanan berpengaruh signifikan terhadap Pengamanan Proyek Konstruksi tower "X" di Surabaya

2. Faktor Peralatan Dan Pakaian Kerja berpengaruh signifikan terhadap Pengamanan Proyek Konstruksi tower "X" di Surabaya

3. Faktor Jalur Kendaraan berpengaruh signifikan terhadap Pengamanan Proyek Konstruksi tower "X" di Surabaya

4. Faktor Kebakaran tidak berpengaruh signifikan terhadap Pengamanan Proyek Konstruksi tower "X" di Surabaya

5. Faktor Peralatan Dan Mesin berpengaruh signifikan terhadap Pengamanan Proyek Konstruksi tower "X" di Surabaya

6. Faktor Listrik Dan Suara berpengaruh signifikan terhadap Pengamanan Proyek Konstruksi tower "X" di Surabaya

7. Faktor Perlindungan Publik tidak berpengaruh signifikan terhadap Pengamanan Proyek Konstruksi tower "X" di Surabaya

8. Faktor Umum berpengaruh signifikan terhadap Pengamanan Proyek Konstruksi tower "X" di Surabaya

9. Faktor Kesehatan Kerja berpengaruh signifikan terhadap Pengamanan Proyek Konstruksi tower "X" di Surabaya.

\section{Saran}

Berdasarkan hasil analisa dan pembahasan yang dilakukan, peneliti memberikan beberapa saran yang dapat memberikan kontribusi untuk meningkatkan Pengamanan Proyek Konstruksi tower " $X$ " di Surabaya serta bagi penelitian selanjutnya. Adapun saran-saran tersebut adalah sebagai berikut:

1. Proyek Konstruksi tower "X" di Surabaya semakin memperhatikan faktor factor kebakaran dalam upaya meningkatkan pengamanan proyek sehingga para pekerja akan dapat bekerja dengan lingkungan yang aman. 
2. Penelitian selanjutnya diharapkan dapat menambahkan atau mengembangkan variabel lain selain dari variabel yang digunakan pada penelitian ini yang diduga mempengaruhi Pengamanan Proyek serta menggunakan metode lainnya seperti kualitatif.

\section{DAFTAR PUSTAKA}

1. Bunial, Muttaqin, dan Rauzana, Faktor-Faktor Penerapan Keselamatan Dan Kesehatan Kerja Yang Mempengaruhi Kinerja Proyek Konstruksi Gedung Di Provinsi Aceh, Jurnal Arsip Rekayasa Sipil dan Perencanaan 1(4);130-137, 2018.

2. Christina, Djakfar, \& Thoyib, Pengaruh Budaya Keselamatan dan Kesehatan Kerja (K3) Terhadap Kinerja Proyek Konstruksi, Jurnal Rekayasa Sipil, Vol. 6, No. 1 -2012 ISSN 1978-5658. 2012.

3. Ervianto, W, Manajemen Proyek Konstruksi (Edisi revisi). Andi Offset, Yogyakarta, 2005

4. Mangkunegara, Manajemen Sumber Daya Manusia. Perusahaan, Remaja Rosdakarya, Bandung, 2013.

5. Suma'mur, Hiegiene Perusahaan dan Keselamatan Kerja, CV. Sagung Seto, Jakarta, 2009. 